\title{
Prenatal Diagnosis for Thalassemia: Sensible or Impractical? - An Indian Context
}

\author{
Arulmani Thiyagarajan* \\ SRM University, India \\ *Corresponding author: Arulmani Thiyagarajan, School of Public Health, SRM University, Chennai, Tamilnadu, India.
}

Submission: 監 March 22, 2018; Published: 眥 September 04, 2018

\section{Introduction}

Thalassemia is a blood inherited disorder caused due to defective hemoglobin synthesis in the red blood cells in the body. It is one of the common genetic disorder, from which nearly 200 million people globally [1] are being affected either as a thalassemia minor or major or sometimes as a carrier-whom only carry genes not affected by symptoms. Most thalassemia carrier are not aware of their carrier status [2], which remains a great threat to transmit the disease. The nature and limited treatment options for the disease imposes a heavy psychosocial burden on patients and their families [3]. Recent advances in the diagnostics and preventive medicine of genetic disorders particularly in thalassemia have improved patient survival through the options like blood transfusion, chelation therapy, and gene therapy [4]. Similarly, patients' well-being has also increased significantly in accordance with technological advancements leading to increased function of their entire family $[1,5]$, having their day today activities normal.

Many studies revealed that diagnosing prenatally through the chorionic villous sampling of carrier mother will have a greater impact in revealing the status of the child whether having thalassemia or not. Unlikely, there are also many ethical issues related to it, which states the outcome of the children survival would be of disparaging. Prenatal diagnosis on fetal blood even if indicated for couple at-risk was not easily accepted. The intensive procedures and the fear of being suspect made their choices against the prenatal diagnosis. And studies also revealed that termination option was the choice they prefer if parents with Thalassemia carrier given the option to comprehensive genetic counseling services after they have been diagnosed. That makes more complicated in terms of diagnosis and screening. A study of Indian context revealed that by and large, parents have no reservations in sharing information on their diagnosis [6], which again makes prenatal diagnosis a complicated choice. Even though the techniques have been introduced long back $[7,8]$, still in some places in India, the services like chorionic villus sampling and DNA analysis in the first trimester is limited, which is being referred to other hospitals.

In spite of the drawbacks, the continuous advances in the knowledge of molecular pathology and improvement in methodologies for detecting mutation and applying vilocentesis in regaining of nucleated fetal cells allowed a fast improvement both in practicality and suitability of prenatal diagnosis [9]. Furthermore, to reduce the option of terminating the pregnancy, pre-conception genetic diagnosis or preimplantation has been sighting up for thalassemia and several other diseases [10]. Prenatal diagnosis is considered as an integral component of the control programme for hemoglobinopathies from the community standpoint. Disease burden estimation, awareness creation in the community, carrier and couple's at-risk identification, and genetic counseling is fundamentals for a dynamic preventive programme. Countries like Cyprus, Greece, the UK, and Italy have successfully launched control programmes and attained outstanding reduction of genetic disorders [11-14]. From previous studies, it is identified that most appropriate time to screen for thalassemia is, during an antenatal check-up in antenatal clinics, high school children, college or university students and extended family members of affected children [15].

Genetic counseling is also one of the important ways to prevent the spread. Counselors and health educators should be completely aware that couple at-risk having a child with genetic disorders, in general, should be given the option of prenatal diagnosis to solve further complications. In the same way, in Sardina birth reduction of major beta-thalassemia major babies from 1:250 to 1:4000 have been achieved by effective genetic counseling with the identification of a maximum number of carriers [16]. Public health education programmes concentrating on targeted or highrisk population is very much needed for the current scenario for providing parental genetic counseling in prenatal diagnosis as well as to fill the knowledge gap in genetic disorders.

\section{References}

1. Mahrokh K, Ahmad E, Heidarali A (2013) Relation between children's well-being and family function in children with thalassemia major in Isfahan in 2013. Global Journal of Health Science 8(12).

2. Alpha Thalassemia. Kids Health.

3. Kurian MA, Li Y, Zhen J, Meyer E, Hai N, et al. (2010) Clinical and molecular characterisation of hereditary dopamine transporter deficiency syndrome: An observational cohort and experimental study. Lancet Neurol 10(1): 54-62. 
4. Thiyagarajan A (2018) Advancement in thalassemia treatment: A view from gene therapy. Clin Pharmacol Biopharm 7(1).

5. Yamashita R, Sobota A, Trachtenberg F, Xu Y, Pakbaz Z, Odame I, et al. (2009) The impact of the child with thalassemia on the family: Parental assessment by child health questionnaire. Blood 114(22): 1371-1371.

6. Shah B, Bhavsar R (2005) Carrier parents of Tay Sachs disease and betathalassemia. Indian Pediatr 42(5): 498-499.

7. Gorakshakar AC, Lulla CP, Nadkarni AH, Pawar AR, Desai SN, et al. (1997) Prenatal diagnosis of beta-thalassemia among Indians using denaturing gradient gel electrophoresis. Hemoglobin 21(5): 421-435.

8. Thakur C, Vaz F, Banerjee M, Kapadia C, Natrajan PG, et al. (2000) Prenatal diagnosis of beta-thalassaemia and other haemoglobinopathies in India. Prenat Diagn 20(3): 194-201.

9. Kan YW, Lee KY, Furbetta M, Angius A, Cao A (1980) Polymorphism of DNA sequence in the beta-globin gene region. Application to prenatal diagnosis of beta 0 thalassemia in Sardinia. N Engl J Med 302(4): 185188.

10. Rosatelli MC, Saba L (2009) Prenatal diagnosis of $\beta$-thalassemias and hemoglobinopathies. Mediterr J Hematol Infect Dis 1(1).
11. Loukopoulos D (1996) Current status of thalassemia and the sickle cell syndromes in Greece. Semin Hematol 33(1): 76-86.

12. Angastiniotis MA, Hadjiminas MG (1981) Prevention of thalassaemia in Cyprus. Lancet Lond Engl 1(8216): 369-371.

13. Cao A (1987) Results of programmes for antenatal detection of thalassemia in reducing the incidence of the disorder. Blood Rev 1(3): 169-176.

14. Petrou M, Modell B (1995) Prenatal screening for haemoglobin disorders. Prenat Diagn 15(13): 1275-1295.

15. Gorakshakar AC, Colah RB (2009) Cascade screening for betathalassemia: A practical approach for identifying and counseling carriers in India. Indian J Community Med Off Publ Indian Assoc Prev Soc Med 34(4): 354-356.

16. Cao A, Rosatelli MC, Galanello R (1996) Control of beta-thalassaemia by carrier screening, genetic counselling and prenatal diagnosis: the Sardinian experience. Ciba Found Symp 197: 137-151.

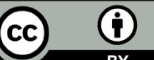

Creative Commons Attribution 4.0 International License

For possible submissions Click Here

\section{Submit Article}

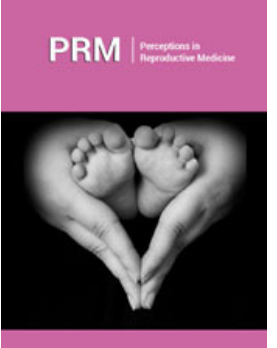

Perceptions in Reproductive Medicine

\section{Benefits of Publishing with us}

- High-level peer review and editorial services

- Freely accessible online immediately upon publication

- Authors retain the copyright to their work

- Licensing it under a Creative Commons license

- Visibility through different online platforms 